\title{
Baicalin prevents the apoptosis of endplate chondrocytes by inhibiting the oxidative stress induced by $\mathrm{H}_{2} \mathrm{O}_{2}$
}

\author{
YUTAO PAN*, DI CHEN*, QINGYOU LU, LIFENG LIU, XIA LI and ZENGCHUN LI \\ Department of Emergency and Trauma Surgery, Shanghai East Hospital Affiliated to Tongji University, \\ Shanghai 200120, P.R. China
}

Received July 6, 2016; Accepted May 8, 2017

DOI: $10.3892 / \mathrm{mmr} .2017 .6904$

\begin{abstract}
Osteoarthritis (OA) is a degenerative disease of articular cartilage. The pathogenesis of OA remains to be fully elucidated, and several studies have found that oxidative stress is important in its pathogenesis. Baicalin is well known and has already been investigated for its role of inhibiting the oxidative stress pathway. Thus, the present study aimed to investigate the role of baicalin on the inhibition of oxidative stress in endplate chondrocytes induced by hydrogen peroxide $\left(\mathrm{H}_{2} \mathrm{O}_{2}\right)$. Following treatment of endplate chondrocytes with different doses of $\mathrm{H}_{2} \mathrm{O}_{2}$ with or without baicalin for different incubation durations, a CCK-8 assay and Annexin V/PI staining were used to measure the cell proliferation and apoptotic rates to identify the optimal experimental conditions. Subsequently, for examining the effects and underlying mechanism of baicalin on oxidative stress, the protein expression levels of cleaved-poly (ADP-ribose) polymerase (PARP), B-cell lymphoma-2-associated $\mathrm{X}$ protein (Bax) and pro-caspase-3 were analyzed using western blot analysis, intracellular anti-oxidant activities, including those of malondialdehyde (MDA), superoxide dismutase (SOD) and nitric oxide (NO), were quantified, and the levels of endothelial nitric oxide synthase (eNOS) were examined using reverse transcription-polymerase chain reaction analysis. The results revealed that the oxidative stress of endplate chondrocytes induced by $0.5 \mathrm{mM} \mathrm{H}_{2} \mathrm{O}_{2}$ for $4 \mathrm{~h}$ were the most appropriate conditions for experiments, and pretreatment with $100 \mu \mathrm{mol} / \mathrm{l}$ baicalin for $1 \mathrm{~h}$ effectively reversed the effect of $\mathrm{H}_{2} \mathrm{O}_{2}$ on the endplate chondrocytes. In addition, Annexin V/PI staining demonstrated that the cell death induced by $\mathrm{H}_{2} \mathrm{O}_{2}$ was apoptotic, and
\end{abstract}

Correspondence to: Dr Zengchun Li or Dr Xia Li, Department of Emergency and Trauma Surgery, Shanghai East Hospital Affiliated to Tongji University, 150 Jimo Road, Shanghai 200120, P.R. China E-mail: 1zc0155@easthospital.cn

E-mail: daxia868@163.com

*Contributed equally

Key words: endplate chondrocyte, baicalin, $\mathrm{H}_{2} \mathrm{O}_{2}$, oxidative stress, apoptosis baicalin reversed the apoptosis induced by oxidative stress. $\mathrm{H}_{2} \mathrm{O}_{2}$ activated PARP cleavage, and the expression of Bax and pro-caspase-3; however, baicalin inhibited the expression of these apoptotic signaling indicators. Baicalin also reduced the levels of MDA, and increased the levels of SOD and NO. Baicalin also significantly elevated the mRNA levels of eNOS in endplate chondrocytes. Therefore, the results of the present study showed that baicalin significantly inhibited the oxidative stress in endplate chondrocytes induced by $\mathrm{H}_{2} \mathrm{O}_{2}$, and decreased cell apoptosis.

\section{Introduction}

Osteoarthritis (OA) is a degenerative disease of articular cartilage, which is characterized by local and progressive destruction of articular cartilage, and osteophyte formation in the subcartilage edges, and is often accompanied by synovial inflammation. At present, the pathogenesis of articular cartilage injury in OA remains to be fully elucidated. Studies in previous decades have confirmed that oxidative stress is important in the pathogenesis and progression of OA $(1,2)$. Oxidative stress is characterized by excessive reactive oxygen species (ROS) production and reduced cellular antioxidant activity, leading to membrane lipid peroxidation and mitochondrial dysfunction (3-5). If oxidative insult persists, programmed cell death is initiated, which can cause apoptosis of chondrocytes and extracellular matrix degradation $(1,2)$.

Oxidative stress is primarily caused by the excessive accumulation of ROS, which include hydrogen peroxide $\left(\mathrm{H}_{2} \mathrm{O}_{2}\right)$, superoxide anions and hydroxyl radicals. $\mathrm{H}_{2} \mathrm{O}_{2}$ is a major component of ROS and is used extensively as an inducer in oxidative stress models (5-9). Therefore, treatment strategies with the potential to prevent oxidative stress induced by $\mathrm{H}_{2} \mathrm{O}_{2}$ are considered valuable for patients with OA. Baicalin is a flavonoid glycoside extracted from a type of traditional Chinese medicine, Scutellaria baicalensis, and its chemical structure has been determined (10). Baicalin has been shown to possess antibacterial, anti-inflammatory and anti-apoptotic properties, and is widely used in the treatment of infectious and inflammatory diseases (8,11-14).

The aim of the present study was to investigate the potential protective effects of baicalin treatment on $\mathrm{H}_{2} \mathrm{O}_{2}$-induced oxidative stress in endplate chondrocytes in vitro, particularly its effect on cell apoptosis. 


\section{Materials and methods}

Isolation and culture of primary rat endplate chondrocytes. A total of 40 4-week-old male Sprague-Dawley rats weighing 160-200 g were obtained from Shanghai SLAC Laboratory Animal Co., Ltd. (Shanghai, China) and housed at a temperature of $26^{\circ} \mathrm{C}, 40-60 \%$ humidity, standard diet and a $14-\mathrm{h}$ light/10-h dark cycle. Rat endplate chondrocytes were obtained following cervical dislocation after anesthesia according to a previous study $(15,16)$. In brief, the region of the lumbar posterior midline was shaved and then covered with sterile drapes. The rats were placed in a prone position on the operating table. Cartilage of the L3-L5 endplates was carefully removed from the vertebrae and placed into a small beaker with high-glucose (4.5 g/l; $25 \mathrm{mM})$ Dulbecco's modified Eagle's medium (DMEM; Gibco; Thermo Fisher Scientific, Inc., Waltham, MA, USA). Sterile ophthalmic scissors were used to cut the tissues into $1-\mathrm{mm}^{3}$ sections, and these were transferred to a $50-\mathrm{ml}$ sterile test tube. The tissues were digested with $0.25 \%$ trypsin (Hyclone; GE Healthcare Life Sciences; Logan, UT, USA) at $37^{\circ} \mathrm{C}$ for $30 \mathrm{~min}$, followed by the addition of $0.2 \%$ collagenase (Sigma; Merck KGaA; Darmstadt, Germany) at $37^{\circ} \mathrm{C}$ for $2 \mathrm{~h}$. Following centrifugation $(400 \mathrm{x}$ g for $10 \mathrm{~min}$ at room temperature), the supernatant was discarded and the tissue suspension was washed three times with DMEM with $10 \%$ heat-inactivated fetal bovine serum (FBS; Gibco; Thermo Fisher Scientific, Inc.). The released cells were cultured in DMEM with $10 \%$ FBS, $100 \mathrm{U} / \mathrm{ml}$ penicillin and $100 \mu \mathrm{g} / \mathrm{ml}$ streptomycin (both from Gibco; Thermo Fisher Scientific, Inc.). The cells were maintained at $37^{\circ} \mathrm{C}$ in a humidified atmosphere of 5\% $\mathrm{CO}_{2}$, and used at passage 4-6 for all experiments. The present study was approved by the Ethics Committee of Shanghai East Hospital Affiliated to Tongji University (Shanghai, China).

Cell viability of endplate chondrocytes treated with $\mathrm{H}_{2} \mathrm{O}_{2}$. The endplate chondrocytes were grown in 96-well plates (BD Biosciences, Franklin Lakes, NJ, USA) at a density of $\sim 1 \mathrm{x} 10^{5} / \mathrm{ml}(200 \mu \mathrm{l} /$ well $)$ in DMEM supplemented with $10 \%$ FBS, $100 \mathrm{U} / \mathrm{ml}$ penicillin and $100 \mu \mathrm{g} / \mathrm{ml}$ streptomycin. After $24 \mathrm{~h}$, the cells were washed with PBS buffer and incubated in serum-free medium at $37^{\circ} \mathrm{C}$ for $12 \mathrm{~h}$. The cells were then washed again and incubated with medium containing different concentrations $\left(0.1,0.5\right.$ and $1.0 \mathrm{mM}$ ) of $\mathrm{H}_{2} \mathrm{O}_{2}$ (Lingfeng Chemicals Co., Ltd., Shanghai, China) at $37^{\circ} \mathrm{C}$ for $4 \mathrm{~h}$, respectively. Untreated cells were referred to as the normal control cells. Cell viability was determined using a CCK-8 assay (Dojindo Molecular Technologies, Inc., Kumamoto, Japan). The CCK-8 reagent was diluted 10 -fold with DMEM prior to being added $(100 \mathrm{ml})$ to each well. After $2.5 \mathrm{~h}$ at $37^{\circ} \mathrm{C}$, sample optical density (OD) values were read at $450 \mathrm{~nm}$ using a multimode microplate reader (FlexStation 3; Molecular Devices LLC, Sunnyvale, CA, USA). The OD450 is proportional to the degree of cell viability. Data are shown as the mean of at least three independent experiments.

Annexin V/PI assay of endplate chondrocytes treated with $\mathrm{H}_{2} \mathrm{O}_{2}$. The apoptosis of endplate chondrocytes induced by $\mathrm{H}_{2} \mathrm{O}_{2}$ was measured using a commercial Annexin V/PI assay kit (Nanjing KeyGen Biotech Co., Ltd., Nanjing, China) according to the manufacturer's protocol. Briefly, the endplate chondrocytes were cultured in 6-well plates (BD Biosciences) at a density of $\sim 1.0 \times 10^{5} / \mathrm{ml}(2 \mathrm{ml} /$ well $)$ and incubated in DMEM supplemented with $10 \%$ FBS, $100 \mathrm{U} / \mathrm{ml}$ penicillin and $100 \mu \mathrm{g} / \mathrm{ml}$ streptomycin. After $24 \mathrm{~h}$, the cells were washed and incubated in serum-free medium for $12 \mathrm{~h}$. The cells were then washed again and incubated in medium with various concentrations of $\mathrm{H}_{2} \mathrm{O}_{2}(0.1,0.5$ and $1.0 \mathrm{mM})$ at $37^{\circ} \mathrm{C}$ for $4 \mathrm{~h}$. Following incubation, the cells were trypsinized and washed with PBS. Following centrifugation at $100 \mathrm{xg}$ for $5 \mathrm{~min}$ at room temperature, the cells were resuspended in $500 \mu \mathrm{l}$ binding buffer. The suspensions were transferred into $1.5-\mathrm{ml}$ tubes, and $5 \mu \mathrm{l}$ of Annexin V and $5 \mu \mathrm{l}$ of PI solution were added. The cells were incubated in the dark at room temperature for $20 \mathrm{~min}$, and flow cytometric analysis was performed using a BD FACSAria II flow cytometer (BD Bioscience). Data were analyzed using BD FACSDiva software version 6.1.3 (BD Bioscience), and Flowjo version 7.6.1 (FlowJo LLC, Ashland, OR, USA). The percentage apoptosis was determined as the percentage of Annexin V-positive/PI-negative cells.

Cell viability of endplate chondrocytes treated with baicalin. The endplate chondrocytes were incubated with $0.5 \mathrm{mM}$ $\mathrm{H}_{2} \mathrm{O}_{2}$ at $37^{\circ} \mathrm{C}$ and $5 \% \mathrm{CO}_{2}$ for $4 \mathrm{~h}$, with baicalin added at different treatment time-points $(-1,0,1$ and $2 \mathrm{~h})$. Untreated cells and cells treated with $\mathrm{H}_{2} \mathrm{O}_{2}$ only were referred as the control groups. The viability of the endplate chondrocytes was determined using a CCK-8 assay, as described above. In addition to determining the optimal incubation duration, the optimal concentration of baicalin on endplate chondrocytes was investigated. The cells were pretreated with baicalin at various concentrations $(50,100$ and $200 \mu \mathrm{mol} / \mathrm{l})$ for $1 \mathrm{~h}$, and were incubated with $0.5 \mathrm{mM} \mathrm{H}_{2} \mathrm{O}_{2}$ at $37^{\circ} \mathrm{C}$ for $4 \mathrm{~h}$, respectively. Untreated cells and cells treated with $\mathrm{H}_{2} \mathrm{O}_{2}$ only were referred as the control groups. As pretreatment of endplate chondrocytes with $100 \mu \mathrm{mol} / 1$ baicalin was optimal for inhibiting the oxidative stress induced by $\mathrm{H}_{2} \mathrm{O}_{2}$, the cell viability was compared between the $\mathrm{H}_{2} \mathrm{O}_{2}$-only group and the groups treated with $\mathrm{H}_{2} \mathrm{O}_{2}$ at different time-points (4, 8, 12 and $24 \mathrm{~h}$ ). Untreated cells were referred to as the control group. All the above data are shown as the mean of at least three independent experiments.

Annexin VIPI assay of endplate chondrocytes pretreated with baicalin. The cells were pretreated with $100 \mu \mathrm{mol} / 1$ for $1 \mathrm{~h}$, and then incubated in medium with $0.5 \mathrm{mM} \mathrm{H}_{2} \mathrm{O}_{2}$ at $37^{\circ} \mathrm{C}$ for $4 \mathrm{~h}$. Based on the previously described method, the inhibitory effect of baicalin on the apoptosis of endplate chondrocytes induced by $\mathrm{H}_{2} \mathrm{O}_{2}$ was measured using an Annexin V/PI assay kit.

Western blot analysis. The protein expression of endplate chondrocytes was evaluated in the groups of chondrocytes treated with $0.5 \mathrm{mM} \mathrm{H}_{2} \mathrm{O}_{2}$ only for $4 \mathrm{~h}$, with $0.5 \mathrm{mM} \mathrm{H}_{2} \mathrm{O}_{2}$ for $4 \mathrm{~h}+100 \mu \mathrm{mol} / 1$ baicalin pretreatment for $1 \mathrm{~h}$, and in normal control group. For the extraction of proteins, the cells were placed in RIPA lysis buffer (Beyotime Institute of Biotechnology, Haimen, China) for $15 \mathrm{~min}$ at $4^{\circ} \mathrm{C}$ and centrifuged at $1,300 \mathrm{x} \mathrm{g}$ for $30 \mathrm{~min}$ at $4^{\circ} \mathrm{C}$. The protein concentrations were determined using a NanoDrop 
instrument, and $40 \mu \mathrm{g}$ of protein from each sample were run on a $15 \%$ SDS-PAGE gels. The separated proteins were transferred onto PVDF membranes. Following blocking with $5 \%$ nonfat dry milk in double-distilled water at room temperature for $1 \mathrm{~h}$, the membranes were washed three times with TBS containing $0.1 \%$ Tween-20 (TBS-T) and incubated overnight at $4^{\circ} \mathrm{C}$ with primary mouse monoclonal anti-PARP (ab203467; 1:500), anti-B-cell lymphoma-2-associated X protein (Bax, ab32503; 1:1,000), anti-pro-caspase-3 (ab13847; 1:500), or anti-GAPDH antibodies (ab8245; 1:500) (all from Abcam, Cambridge, MA, USA). The membranes were then washed three times with TBS-T, followed by $1 \mathrm{~h}$ incubation at room temperature in a 1:1,000 dilution of goat anti-mouse/rabbit HRP antibody (715-035-150/415-035-166; Jackson ImmunoResearch Laboratories, Inc., West Grove, PA, USA). Following incubation, the membranes were washed three times with TBS-T. Immune complexes were visualized using enhanced chemiluminescence followed by exposure to a Tanon 5200 instrument (Tanon Science and Technology Co., Ltd., Shanghai, China). Data were normalized to the GAPDH content of the same sample.

Measurement of oxidative activity. The oxidative activities were measured at 6,12 and $24 \mathrm{~h}$ in the $0.5 \mathrm{mM} \mathrm{H}_{2} \mathrm{O}_{2}, 0.5 \mathrm{mM}$ $\mathrm{H}_{2} \mathrm{O}_{2}+100 \mu \mathrm{mol} / 1$ baicalin pretreatment for $1 \mathrm{~h}$, and normal control groups. The concentrations of malondialdehyde (MDA), superoxide dismutase (SOD) and nitric oxide (NO) were assessed using dedicated kits (Nanjing KeyGen Biotech Co., Ltd.) according to the manufacturer's protocols.

Reverse transcription-quantitative polymerase chain reaction (RT-qPCR) analysis. The mRNA expression levels of endothelial nitric oxide synthase (eNOS) were determined in the groups treated with $0.5 \mathrm{mM} \mathrm{H}_{2} \mathrm{O}_{2}$ only for $4 \mathrm{~h}, 0.5 \mathrm{mM}$ $\mathrm{H}_{2} \mathrm{O}_{2}$ for $4 \mathrm{~h}+100 \mu \mathrm{mol} / \mathrm{l}$ baicalin pretreatment for $1 \mathrm{~h}$, and the normal control group. Total cellular RNA was extracted from the endplate chondrocytes using TRIzol (Invitrogen; Thermo Fisher Scientific, Inc.). OLIGO was used as the reverse transcription primer, and the total RNA was extracted from the cells of each group as the template, which was then reverse transcribed into cDNA under the RT enzyme. The reaction system included 500 ng RNA template, $5 X$ buffer $2 \mu$, PrimeScript RT enzyme mix I $0.5 \mu \mathrm{l}, 10 \mu \mathrm{mol} / 150 \mathrm{M}$ OLIGO $0.5 \mu \mathrm{l}$ and $100 \mu \mathrm{M}$ random 6 mers $0.5 \mu \mathrm{l}$. DEPC water was added up to $10 \mu \mathrm{l}$ at $37^{\circ} \mathrm{C}$ for $15 \mathrm{~min}$. PCR amplification was performed in a $20 \mu 1$ reaction volume. The primer sequences were as follows: eNOS forward, 5'-CCAGCTAGCCAAAGTCACCAT-3' and reverse, 5'-GTCTCGGAGCCATACAGGATT-3'; GAPDH forward, 5'-CGGAGTCAACGGATTTGGTCGTAT-3' and reverse, 5'-AGCCTTCTCCATGGTGGTGAAGAC-3'. Triplicate reactions were run with a volume of $20 \mu \mathrm{l}$, containing $2 \mu \mathrm{l}$ cDNA, $10 \mu \mathrm{l}$ 2X SYBR-Green mix, $6 \mu \mathrm{l}$ dd $_{2} \mathrm{O}, 1 \mu \mathrm{l}$ PCR forward primer $(10 \mu \mathrm{M})$ and $1 \mu \mathrm{l}$ PCR reverse primer $(10 \mu \mathrm{M})$. Following an initial denaturation at $95^{\circ} \mathrm{C}$ for $5 \mathrm{~min}$, the PCR conditions were as follows: 35 cycles of denaturation at $95^{\circ} \mathrm{C}$ for $30 \mathrm{sec}$, annealing at $55^{\circ} \mathrm{C}$ for $30 \mathrm{sec}$, and extension at $72^{\circ} \mathrm{C}$ for $30 \mathrm{sec}$. The $2^{-\Delta \Delta \mathrm{Cq}}$ (quantification cycle) method (17) was used to calculate the mRNA expression levels of eNOS in each sample. Data were normalized to the GAPDH content of the same sample.
Statistical analysis. All data are expressed as the mean \pm standard deviation. Statistical analysis was performed using Student's t-test and one-way analysis of variance using SPSS version 18.0 software (SPSS, Inc., Chicago, IL, USA). $\mathrm{P}<0.05$ was considered to indicate a statistically significant difference.

\section{Results}

$\mathrm{H}_{2} \mathrm{O}_{2}$ induces apoptotic cell death of endplate chondrocytes. To characterize the effects of $\mathrm{H}_{2} \mathrm{O}_{2}$ on the induction of cell death of endplate chondrocytes, cell viability and apoptotic rates were detected. As $\mathrm{H}_{2} \mathrm{O}_{2}$ concentration increased, the cell viability gradually decreased (Fig. $1 \mathrm{~A} ; \mathrm{P}<0.05$ ), and apoptotic cell death was significantly increased (Fig. 1B-F; P<0.05). On the basis of these experiments on cell viability and the Annexin V/PI staining assay, $0.5 \mathrm{mM} \mathrm{H}_{2} \mathrm{O}_{2}$ was selected as a model dose for the following experiments.

Baicalin inhibits apoptotic cell death of endplate chondrocytes induced by $\mathrm{H}_{2} \mathrm{O}_{2}$. As shown in Fig. $2 \mathrm{~A}$, cell viability was highest when endplate chondrocytes were pretreated with baicalin for $1 \mathrm{~h}(\mathrm{P}<0.05)$. Subsequently, the cell viability gradually decreased when the endplate chondrocytes were treated with baicalin at or following the start of incubation with $\mathrm{H}_{2} \mathrm{O}_{2}$. Without the coexistence of $\mathrm{H}_{2} \mathrm{O}_{2}$, no significant differences in cell viability were observed among the group pretreated with $50 \mu \mathrm{mol} / 1$ baicalin, the group pretreated with $100 \mu \mathrm{mol} / 1$ baicalin and the control group $(\mathrm{P}>0.05)$. However, when the pretreatment concentration of Baicalin reached $200 \mu \mathrm{mol} / 1$, the cell viability of endplate chondrocytes was significantly lower, compared with that in the control ( $\mathrm{P}<0.05$, Fig. 2B). Furthermore, in the cells incubated with $0.5 \mathrm{mM} \mathrm{H}_{2} \mathrm{O}_{2}$ for $4 \mathrm{~h}$ with baicalin pretreatment for $1 \mathrm{~h}$, the viability of cells in the group pretreated with $100 \mu \mathrm{mol} / 1$ baicalin was significantly higher, compared with that in the other two groups $(\mathrm{P}<0.05)$, which was considered the optimal dose for application in the subsequent experiments (Fig. 2B). As shown in Fig. 2C, compared with the group treated with $\mathrm{H}_{2} \mathrm{O}_{2}$ alone, cell death was significantly decreased in the group treated with $\mathrm{H}_{2} \mathrm{O}_{2}$ +baicalin at 4, 8, 12 and $24 \mathrm{~h}(\mathrm{P}<0.05)$, which suggested that baicalin may inhibit the cell apoptosis induced by $\mathrm{H}_{2} \mathrm{O}_{2}$. The results of the Annexin V/PI staining assay (Fig. 2D-F) also showed that baicalin inhibited the cell apoptosis induced by $\mathrm{H}_{2} \mathrm{O}_{2}$.

Baicalin inhibits the activation of the apoptotic cell death pathway induced by $\mathrm{H}_{2} \mathrm{O}_{2}$. Classic apoptotic cell death is induced through a pathway, which involves the cleavage of PARP and pro-caspase-3, and the activation of Bax. As shown in Fig. 3A and B, the protein expression of cleaved PARP, Bax and pro-caspase-3 proteins were determined following treatment of the endplate chondrocytes with $0.5 \mathrm{mM} \mathrm{H}_{2} \mathrm{O}_{2}$ for $4 \mathrm{~h}$, which were significantly higher, compared with that in the normal control $(\mathrm{P}<0.05)$. By contrast, baicalin pretreatment downregulated the protein expression levels of cleaved PARP, Bax and pro-caspase-3 $(\mathrm{P}<0.05)$. The quantified the results of western blot analysis are shown in Fig. 3B.

Baicalin decreases the oxidative activity in endplate chondrocytes induced by $\mathrm{H}_{2} \mathrm{O}_{2}$. As a biomarker of oxidative stress, 

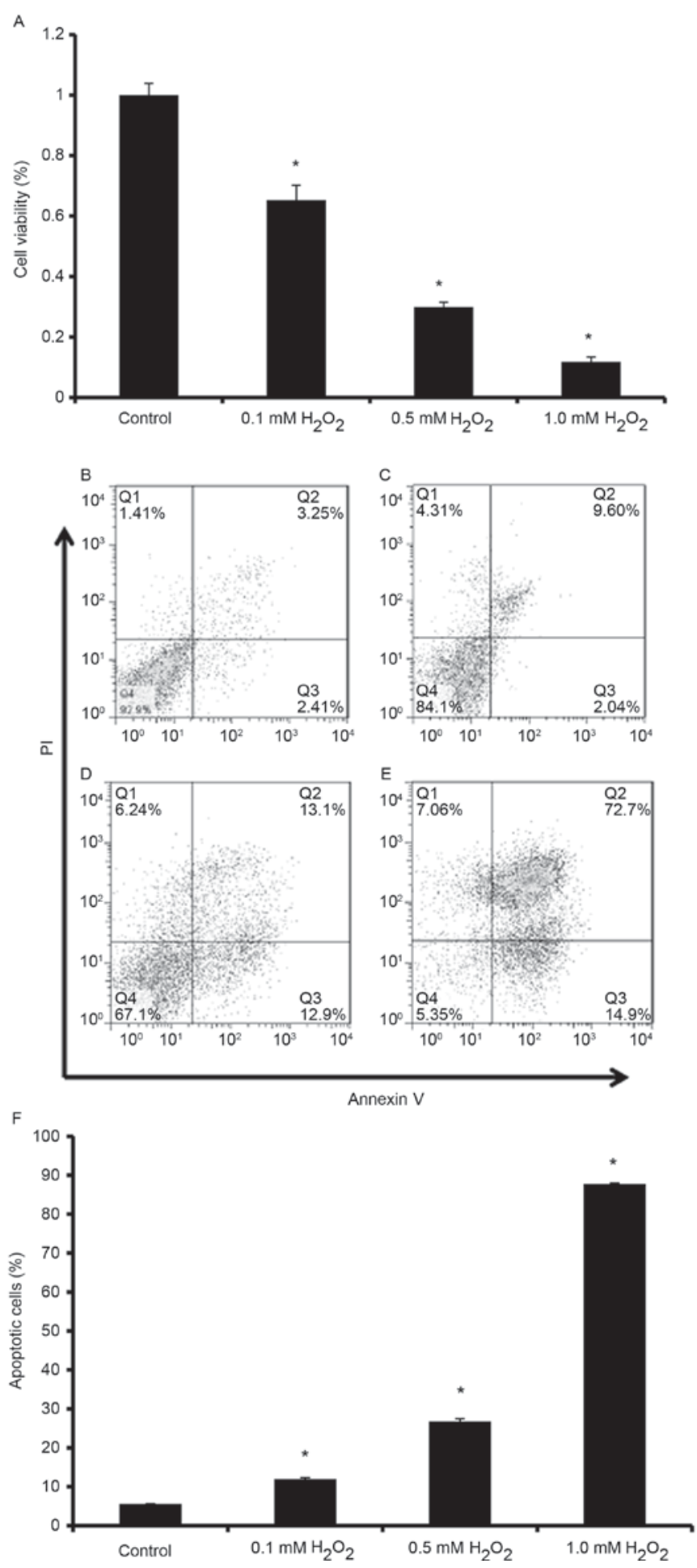

Figure 1. Effect of $\mathrm{H}_{2} \mathrm{O}_{2}$ on endplate chondrocytes. (A) Cell viability of endplate chondrocytes treated with $\mathrm{H}_{2} \mathrm{O}_{2}$ at different concentrations $(0.1$, 0.5 and $1.0 \mathrm{mM}$ ). Apoptosis of endplate chondrocytes induced by $\mathrm{H}_{2} \mathrm{O}_{2}$ were examined at different concentrations in the (B) control; (C) $0.1 \mathrm{mM}$; (D) $0.5 \mathrm{mM}$; (E) $1.0 \mathrm{mM}$ groups. (F) Apoptotic rates of endplate chondrocytes treated with $\mathrm{H}_{2} \mathrm{O}_{2}$ at different concentrations $(0.1,0.5$ and $1.0 \mathrm{mM})$. Data are presented as the mean \pm standard error of the mean. " $\mathrm{P}<0.05 \mathrm{H}_{2} \mathrm{O}_{2}$ vs. control groups. $\mathrm{H}_{2} \mathrm{O}_{2}$, hydrogen peroxide.

the levels of MDA in endplate chondrocytes were increased by $\mathrm{H}_{2} \mathrm{O}_{2}$ treatment at 6,12 and $24 \mathrm{~h}(\mathrm{P}<0.05)$, and this was reversed by baicalin at all time-points $(\mathrm{P}<0.05$; Fig. $4 \mathrm{~A})$. As an enzyme, which regulates oxidative stress, the levels

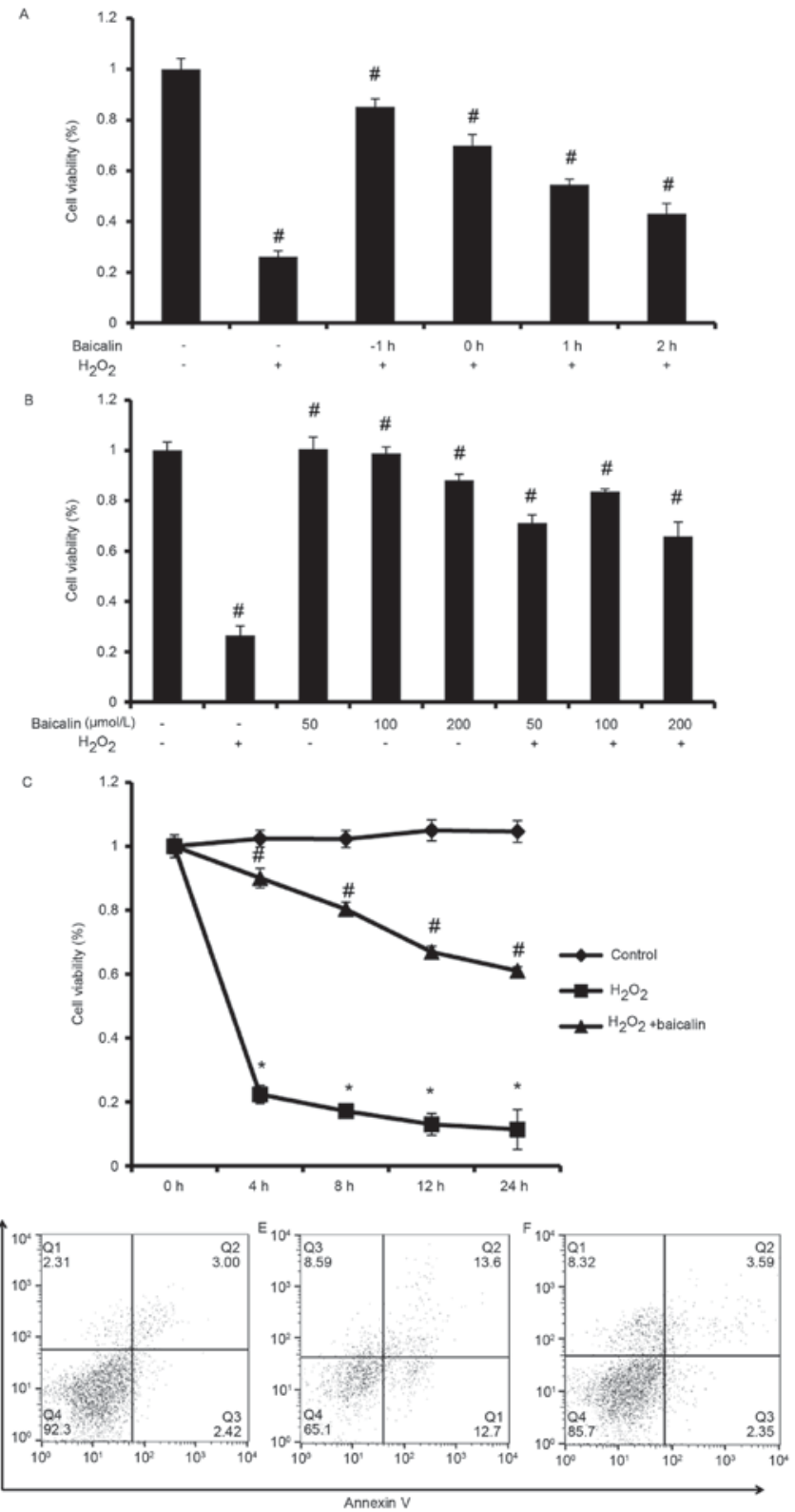

Figure 2. Effects of baicalin on endplate chondrocytes. (A) Effects of baicalin treatment on $\mathrm{H}_{2} \mathrm{O}_{2}$-induced loss of endplate chondrocytes at different timepoints $(-1,0,1$ and $2 \mathrm{~h})$. (B) Effects of $1 \mathrm{~h}$ baicalin treatment on endplate chondrocytes at various concentrations (50,100 and $200 \mu \mathrm{mol} / \mathrm{l})$ with or without $\mathrm{H}_{2} \mathrm{O}_{2}$. (C) Effects of $1 \mathrm{~h}$ baicalin treatment on endplate chondrocytes at different time-points $(4,8,12$ and $24 \mathrm{~h})$ with $\mathrm{H}_{2} \mathrm{O}_{2}$. Data are presented as the mean \pm standard error of the mean. ${ }^{*} " * \mathrm{P}<0.05 \mathrm{H}_{2} \mathrm{O}_{2}$ vs. control group, baicalin $+\mathrm{H}_{2} \mathrm{O}_{2}$ vs. control groups. Inhibitory effects of baicalin on the apoptosis of endplate chondrocytes induced by $\mathrm{H}_{2} \mathrm{O}_{2}$ were determined in the (D) control, (E) $\mathrm{H}_{2} \mathrm{O}_{2}$ (F) baicalin $+\mathrm{H}_{2} \mathrm{O}_{2}$ groups. The results of the Annexin V/PI staining assay showed that baicalin inhibited the cell apoptosis induced by $\mathrm{H}_{2} \mathrm{O}_{2} \cdot \mathrm{H}_{2} \mathrm{O}_{2}$, hydrogen peroxide.

of SOD were significantly decreased by exposure to $\mathrm{H}_{2} \mathrm{O}_{2}$ $(\mathrm{P}<0.05)$, however, pretreatment with baicalin for $1 \mathrm{~h}$ effectively elevated levels of SOD in endplate chondrocytes at the various time-points $(\mathrm{P}<0.05$; Fig. 4B). The effects of baicalin on oxidative activity were further verified by assessing levels of NO, a free radical signaling mediator. The levels of $\mathrm{NO}$ were significantly decreased in the $\mathrm{H}_{2} \mathrm{O}_{2}$-induced endplate chondrocytes $(\mathrm{P}<0.05)$, and this decrease of $\mathrm{NO}$ was reversed by baicalin at 6,12 and $24 \mathrm{~h}(\mathrm{P}<0.05$; Fig. $4 \mathrm{C})$. The mRNA 

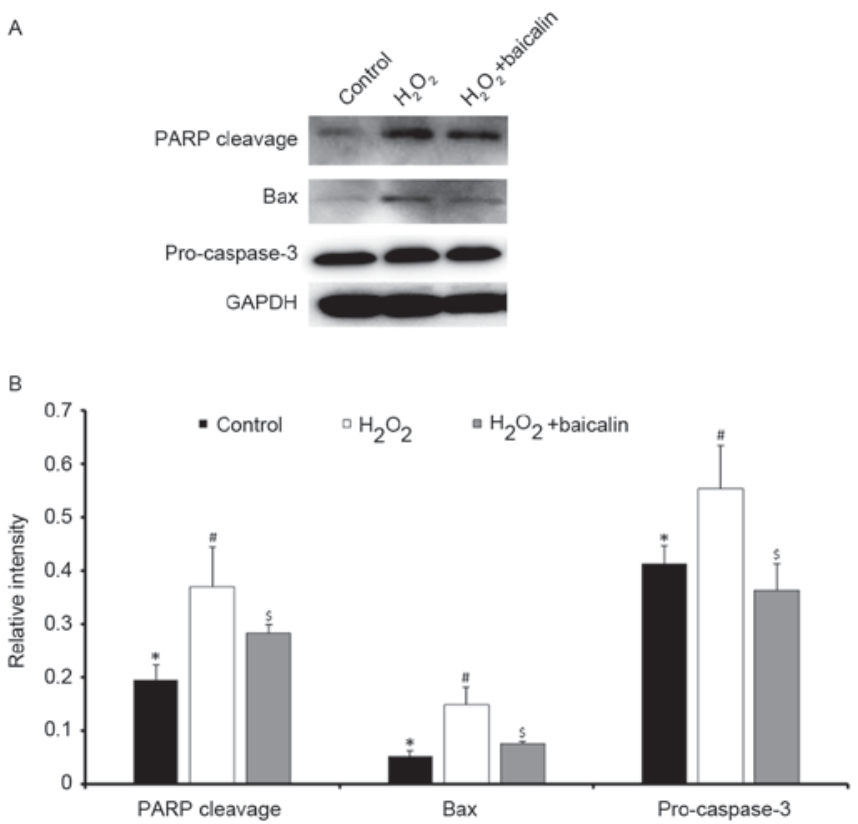

Figure 3. Effect of baicalin on the apoptotic cell death pathway. (A) Western blot analysis of the effects of $1 \mathrm{~h}$ baicalin pretreatment on protein levels of apoptosis-related molecules with or without $\mathrm{H}_{2} \mathrm{O}_{2}$ in endplate chondrocytes Compared with the control group, $\mathrm{H}_{2} \mathrm{O}_{2}$ downregulated the protein expression levels of cleaved PARP, Bax and pro-caspase-3, whereas baicalin reversed and upregulated the expression of apoptosis-related proteins. (B) Quantification of the results of western blot analysis. ${ }^{*, \#, \$} \mathrm{P}<0.05 \mathrm{H}_{2} \mathrm{O}_{2}$, baicalin $\mathrm{H}_{2} \mathrm{O}_{2}$ vs. the control groups. $\mathrm{H}_{2} \mathrm{O}_{2}$, hydrogen peroxide; PARP, poly (ADP-ribose) polymerase; Bax, B-cell lymphoma-2-associated $\mathrm{X}$ protein.

levels of eNOS, an enzyme, which functions in catalyzing the release of $\mathrm{NO}$, were also investigated. The mRNA expression of eNOS was downregulated by $\mathrm{H}_{2} \mathrm{O}_{2}$, and this was reversed by baicalin $(\mathrm{P}<0.05$; Fig. 5$)$.

\section{Discussion}

In the present study, a model of $0.5 \mathrm{mM} \mathrm{H}_{2} \mathrm{O}_{2}$-induced oxidative stress was successfully induced in endplate chondrocytes, which was characterized by reduced cell viability, increased intracellular ROS and reduced intracellular antioxidant activity. These pathophysiological processes led to apoptosis by activation of the intrinsic apoptotic pathway. As a flavonoid glycoside extracted from a type of traditional Chinese medicine, Scutellaria baicalensis, baicalin has been reported to significantly attenuate oxidative injury, and partially prevent apoptosis during the oxidative stress reaction $(8,10-14,18)$. For example, Lin et al $(8,11)$ found that baicalin ameliorated $\mathrm{H}_{2} \mathrm{O}_{2}$-induced cytotoxicity in a human renal proximal tubular epithelial cell line (HK-2 cells), and showed effects against renal ischemia-reperfusion injury through the inhibition of inflammation and apoptosis. Therefore, the present study investigated the potential protective effects of baicalin treatment on $\mathrm{H}_{2} \mathrm{O}_{2}$-induced oxidative stress in endplate chondrocytes in vitro.

Initially, different time-points of induction with baicalin incubation under $\mathrm{H}_{2} \mathrm{O}_{2}$ stimulation were investigated, which showed that $1 \mathrm{~h}$ pretreatment with baicalin exhibited optimal protective effects. Secondly, it was observed that the potential protective effects of baicalin pretreatment against
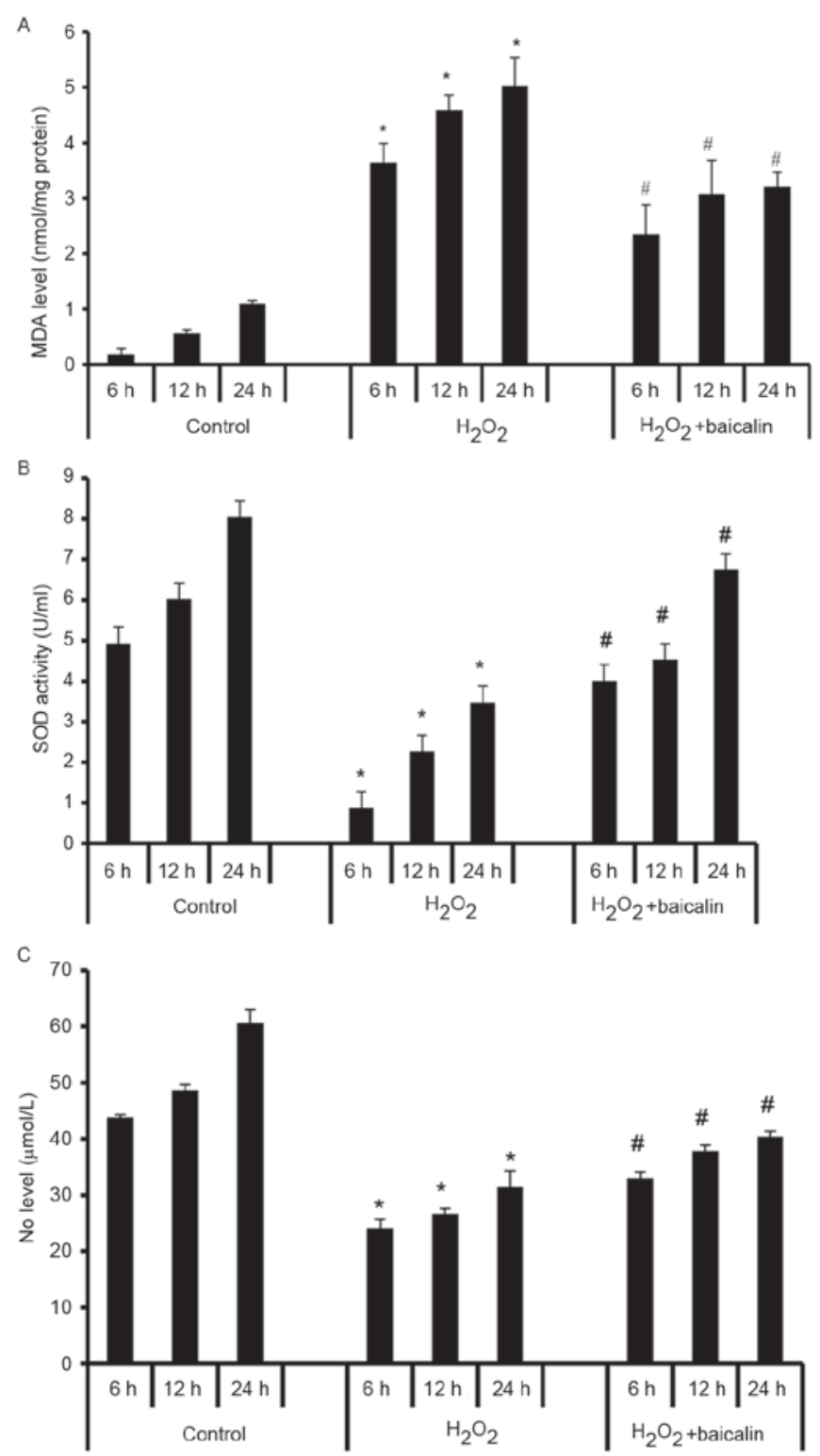

Figure 4. Effects of $1 \mathrm{~h}$ baicalin pretreatment on oxidative activity in endplate chondrocytes induced by $\mathrm{H}_{2} \mathrm{O}_{2}$ at the different time-points $(6,12$ and $24 \mathrm{~h})$. Baicalin suppressed oxidative activity in endplate chondrocytes induced by $\mathrm{H}_{2} \mathrm{O}_{2}$, (A) including effectively reducing levels of MDA, (B) increasing levels of SOD, and (C) elevating NO activity. Data are presented as the mean \pm standard error of the mean. ${ }^{*}, \#<0.05 \mathrm{H}_{2} \mathrm{O}_{2}$, baicalin $+\mathrm{H}_{2} \mathrm{O}_{2}$ vs. the control groups. MDA, malondialdehyde; SOD, superoxide dismutase; NO, nitric oxide.

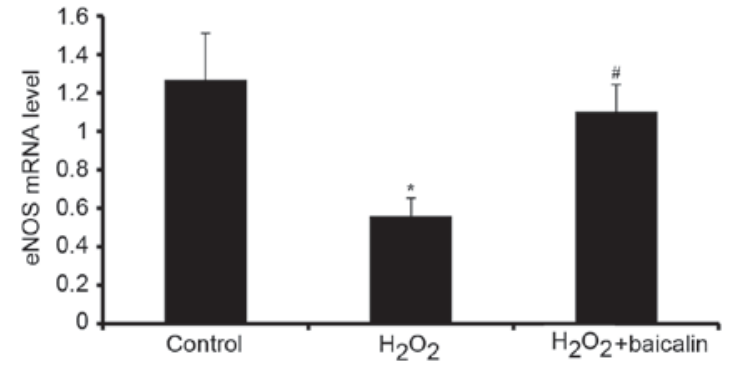

Figure 5. Effects of $1 \mathrm{~h}$ baicalin pretreatment on mRNA expression levels of eNOS in endplate chondrocytes induced by $\mathrm{H}_{2} \mathrm{O}_{2}$ for $4 \mathrm{~h}$. mRNA levels of eNOS were downregulated by $\mathrm{H}_{2} \mathrm{O}_{2}$, which was reversed by baicalin. Data are presented as the mean \pm standard error of the mean. ${ }^{*} " \#<0.05 \mathrm{H}_{2} \mathrm{O}_{2}$, baicalin $+\mathrm{H}_{2} \mathrm{O}_{2}$ vs. the control groups. $\mathrm{H}_{2} \mathrm{O}_{2}$, hydrogen peroxide; eNOS, endothelial nitric oxide synthase. 
oxidative stress-related injury in endplate chondrocytes were dose-dependent. However, baicalin significantly decreased cell viability when its concentration reached $200 \mu \mathrm{mol} / 1$. Therefore, to achieve optimal protective effects, $100 \mu \mathrm{mol} / \mathrm{l}$ baicalin was selected as the optimal concentration for inhibiting oxidative stress in endplate chondrocytes induced by $\mathrm{H}_{2} \mathrm{O}_{2}$.

In the present study, the protective effects of baicalin on oxidative stress of endplate chondrocytes induced by $\mathrm{H}_{2} \mathrm{O}_{2}$ were confirmed through the analysis of cell viability. The cell viability of endplate chondrocytes stimulated by $\mathrm{H}_{2} \mathrm{O}_{2}$ was significantly lower, compared with that in than the normal control, as detected by the CCK-8 assay. Notably, a significant increase in cell viability was observed following baicalin pretreatment for $1 \mathrm{~h}$ at the various time-points. Baicalin was found to inhibit the activation of the apoptotic cell death pathway triggered by $\mathrm{H}_{2} \mathrm{O}_{2}$. Classic apoptotic cell death is induced through a pathway involving the cleavage of PARP and pro-caspase-3, and the activation of Bax (19-21). The abnormally high expression levels of cleaved PARP, Bax and pro-caspase- 3 induced by $\mathrm{H}_{2} \mathrm{O}_{2}$ were significantly reversed by pretreatment with baicalin. In addition, baicalin suppressed oxidative activity in the endplate chondrocytes induced by $\mathrm{H}_{2} \mathrm{O}_{2}$, via effectively reducing levels of MDA, increasing levels of SOD, and elevating NO activities $(5,9,22)$. eNOS, an enzyme which activates the expression of NO (23-25), was also shown to be increased following pretreatment with baicalin, which suggested that baicalin also inhibited the apoptosis through upregulating the expression of eNOS.

However, the mechanism of baicalin-mediated protection against oxidative stress remains to be fully elucidated. Chen et al (18) reported that baicalin inhibited oxidative-stress-induced apoptosis via modulating the activation of extracellular signal-regulated kinases and inducing the gene expression of heme oxygenase-1 in rat C6 glioma cells. Lin et al (8) reported that the effect of baicalin was through the inhibition of endoplasmic reticulum stress and the activation of nuclear factor erythroid 2-related factor 2 signaling, which were important during baicalin-mediated protection. The targets of baicalin also remain to be fully elucidated. A previous study indicated that baicalin activates AMP-activated protein kinase (AMPK) through the $\mathrm{Ca}^{2+} /$ calmodulin-dependent protein kinase kinase $\beta$ (CaMKK $\beta$ )-dependent pathway in HeLa and A549 cells (26). AMPK is important in cell physiology and also affects the cell response to oxidative stress. However, at present, no direct association between the renal protective effects of baicalin and activation of the $\mathrm{Ca}^{2+} / \mathrm{CaMKK} \beta$-AMPK pathway has been reported. Peroxisome proliferator-activated receptor- $\gamma$ (PPAR $\gamma$ ) has also been suggested as a target of baicalin (27). Baicalin was found to activate PPAR $\gamma$ and suppress downstream nuclear factor- $\mathrm{kB}$-mediated inflammation in aged rat kidneys. In addition, studies have suggested other potential targets, including the proteasome (28), macrophages (29) and notch signaling (30). These possibilities were not examined in the present study, and warrant further investigation.

In conclusion, the results of the present study suggested that baicalin pretreatment protected endplate chondrocytes from the oxidative stress-related damage induced by $\mathrm{H}_{2} \mathrm{O}_{2}$. The role of baicalin was predominantly based on inhibiting the production of ROS, increasing intracellular antioxidants and attenuating apoptosis. The results of the present study require verification in future in vivo investigations, however, the results provide further insight into the potential benefits of baicalin for patients with oxidative stress-related diseases, including OA.

\section{Acknowledgements}

This study was supported by the National Science Foundation for Young Scholars of China (grant no. 81601675 to Dr Yutao Pan).

\section{References}

1. Henrotin YE, Bruckner P and Pujol JP: The role of reactive oxygen species in homeostasis and degradation of cartilage. Osteoarthritis Cartilage 11: 747-755, 2003.

2. Henrotin Y, Kurz B and Aigner T: Oxygen and reactive oxygen species in cartilage degradation: Friends or foes? Osteoarthritis Cartilage 13: 643-654, 2005.

3. Rocha M, Apostolova N, Hernandez-Mijares A, Herance R and Victor VM: Oxidative stress and endothelial dysfunction in cardiovascular disease: Mitochondria-targeted therapeutics. Curr Med Chem 17: 3827-3841, 2010.

4. Ying W and Xiong ZG: Oxidative stress and NAD+ in ischemic brain injury: Current advances and future perspectives. Curr Med Chem 17: 2152-2158, 2010.

5. Mao CY, Lu HB, Kong N, Li JY, Liu M, Yang CY and Yang P: Levocarnitine protects $\mathrm{H} 9 \mathrm{c} 2$ rat cardiomyocytes from $\mathrm{H} 2 \mathrm{O} 2$-induced mitochondrial dysfunction and apoptosis. Int J Med Sci 11: 1107-1115, 2014.

6. Nogueira-Pedro A, Cesário TA, Dias CC, Origassa CS, Eça LP, Paredes-Gamero EJ and Ferreira AT: Hydrogen peroxide (H2O2) induces leukemic but not normal hematopoietic cell death in a dose-dependent manner. Cancer Cell Int 13: 123, 2013.

7. Pomari E, Stefanon B and Colitti M: Effect of plant extracts on $\mathrm{H} 2 \mathrm{O} 2$-induced inflammatory gene expression in macrophages. J Inflamm Res 7: 103-112, 2014.

8. Lin M, Li L, Zhang Y, Zheng L, Xu M, Rong R and Zhu T: Baicalin ameliorates $\mathrm{H} 2 \mathrm{O} 2$ induced cytotoxicity in HK-2 cells through the inhibition of ER stress and the activation of Nrf2 signaling. Int J Mol Sci 15: 12507-12522, 2014.

9. Chen S, Tang Y, Qian Y, Chen R, Zhang L, Wo L and Chai H: Allicin prevents $\mathrm{H}_{2} \mathrm{O}_{2}$-induced apoptosis of HUVECs by inhibiting an oxidative stress pathway. BMC Complement Altern Med 14: 321, 2014.

10. Cao Y, Mao X, Sun C, Zheng P, Gao J, Wang X, Min D, Sun H, Xie N and Cai J: Baicalin attenuates global cerebral ischemia/reperfusion injury in gerbils via anti-oxidative and anti-apoptotic pathways. Brain Res Bull 85: 396-402, 2011.

11. Lin M, Li L, Li L, Pokhrel G, Qi G, Rong R and Zhu T: The protective effect of baicalin against renal ischemia-reperfusion injury through inhibition of inflammation and apoptosis. BMC Complement Altern Med 14: 19, 2014.

12. Tang YJ, Zhou FW, Luo ZQ, Li XZ, Yan HM, Wang MJ, Huang FR and Yue SJ: Multiple therapeutic effects of adjunctive baicalin therapy in experimental bacterial meningitis. Inflammation 33: 180-188, 2010.

13. Zhu J, Wang J, Sheng Y, Zou Y, Bo L, Wang F, Lou J, Fan X, Bao R, Wu Y, et al: Baicalin improves survival in a murine model of polymicrobial sepsis via suppressing inflammatory response and lymphocyte apoptosis. PLoS One 7: e35523, 2012.

14. Xiping Z, Guanghua F, Jinxian H, Weihong W, Rujun X, Wei Z, Jing Y, Qijun Y, Meijuan Y, Qing W and Lini F: Baicalin protects thymus of rats with severe acute pancreatitis. Inflammation 33: $157-165,2010$.

15. Wang YJ, Shi Q, Sun P, Zhou Q, Darowish M, Li TF, Dong YF, Lu WW and Leong JC: Insulin-like growth factor-1 treatment prevents anti-Fas antibody-induced apoptosis in endplate chondrocytes. Spine (Phila Pa 1976) 31: 736-741, 2006.

16. Yuan FL, Wang HR, Zhao MD, Yuan W, Cao L, Duan PG Jiang YQ, Li XL and Dong J: Ovarian cancer G protein-coupled receptor 1 is involved in acid-induced apoptosis of endplate chondrocytes in intervertebral discs. J Bone Miner Res 29: 67-77, 2014. 
17. Livak KJ and Schmittgen TD: Analysis of relative gene expression data using real-time quantitative PCR and the 2(-Delta Delta C(T)) method. Methods 25: 402-408, 2001.

18. Chen YC, Chow JM, Lin CW, Wu CY and Shen SC: Baicalein inhibition of oxidative-stress-induced apoptosis via modulation of ERKs activation and induction of $\mathrm{HO}-1$ gene expression in rat glioma cells C6. Toxicol Appl Pharmacol 216: 263-273, 2006.

19. Boulares AH, Yakovlev AG, Ivanova V, Stoica BA, Wang G, Iyer S and Smulson M: Role of poly(ADP-ribose) polymerase (PARP) cleavage in apoptosis. Caspase 3-resistant PARP mutant increases rates of apoptosis in transfected cells. J Biol Chem 274: 22932-22940, 1999.

20. Ruemmele FM, Dionne S, Qureshi I, Sarma DS, Levy E and Seidman EG: Butyrate mediates Caco-2 cell apoptosis via up-regulation of pro-apoptotic BAK and inducing caspase-3 mediated cleavage of poly-(ADP-ribose) polymerase (PARP). Cell Death Differ 6: 729-735, 1999.

21. Hoetelmans R, van Slooten HJ, Keijzer R, Erkeland S, van de Velde CJ and Dierendonck JH: Bcl-2 and Bax proteins are present in interphase nuclei of mammalian cells. Cell Death Differ 7: 384-392, 2000.

22. Liao JK, Shin WS, Lee WY and Clark SL: Oxidized low-density lipoprotein decreases the expression of endothelial nitric oxide synthase. J Biol Chem 270: 319-324, 1995.

23. Knowles RG and Moncada S: Nitric oxide synthases in mammals. Biochem J 298: 249-258, 1994.

24. Chen CA, Wang TY, Varadharaj S, Reyes LA, Hemann C, Talukder MA, Chen YR, Druhan LJ and Zweier JL: S-glutathionylation uncouples eNOS and regulates its cellular and vascular function. Nature 468: 1115-1118, 2010.
25. Wu JR, Hsu JH, Dai ZK, Wu BN, Chen IJ, Liou SF and Yeh JL: Activation of endothelial NO synthase by a xanthine derivative ameliorates hypoxia-induced apoptosis in endothelial progenitor cells. J Pharm Pharmacol 68: 810-818, 2016.

26. Ma Y, Yang F, Wang Y, Du Z, Liu D, Guo H, Shen J and Peng H: CaMKK $\beta$ is involved in AMP-activated protein kinase activation by baicalin in LKB1 deficient cell lines. PLoS One 7: e47900, 2012.

27. Lim HA, Lee EK, Kim JM, Park MH, Kim DH, Choi YJ, Ha YM, Yoon JH, Choi JS, Yu BP and Chung HY: PPAR y activation by baicalin suppresses NF- $\kappa \mathrm{B}$-mediated inflammation in aged rat kidney. Biogerontology 13: 133-145, 2012.

28. Wu YX, Sato E, Kimura W and Miura N: Baicalin and scutellarin are proteasome inhibitors that specifically target chymotrypsin-like catalytic activity. Phytother Res 27: 1362-1367, 2013

29. Liu LL, Gong LK, Wang H, Xiao Y, Wu XF, Zhang YH, Xue X, Qi XM and Ren J: Baicalin inhibits macrophage activation by lipopolysaccharide and protects mice from endotoxin shock. Biochem Pharmacol 75: 914-922, 2008.

30. Wang AM, Ku HH, Liang YC, Chen YC, Hwu YM and Yeh TS: The autonomous notch signal pathway is activated by baicalin and baicalein but is suppressed by niclosamide in K562 cells. J Cell Biochem 106: 682-692, 2009. 